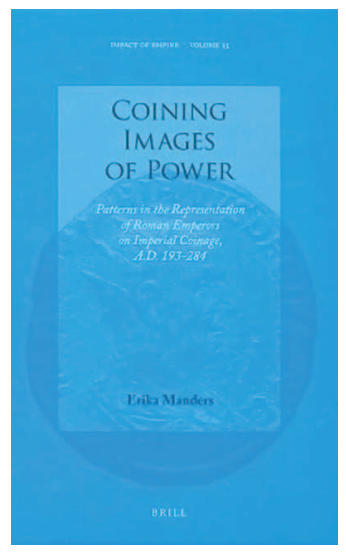

\title{
Katarzyna Balbuza \\ (Poznań) \\ AUTOPREZENTACJA CESARZY RZYMSKICH W MENNICTWIE II I III WIEKU PO CHR.
}

DOI 10.14746/SEG.2014.9.17

Erika Manders, Coining Images of Power. Patterns in the Representation of Roman Emperors on Imperial Coinage A.D. 193-284, Brill Academic Publishers, Leiden-Boston-Tokyo 2012 [=Impact of Empire, 15], $363 \mathrm{~s}$.

Diachroniczną analizę typologii monet rzymskich, wybitych w niespokojnych dla cesarstwa rzymskiego latach 193-284 po Chr. przez rządzących nim 35 cesarzy (od Pertynaksa do Dioklecjana), Erika Manders oparła na zespole 8227 monet. Przez pryzmat legend i ikonografii monet, postrzeganych jako skuteczny środek propagandy cesarskiej, autorka podjęła próbę odczytania istoty autoprezentacji cesarzy rzymskich.

Badania nad ideologią cesarską przeprowadziła Manders, stosując metodologię Carlosa Noreñy ${ }^{1}$. Materiał badawczy podzieliła na trzynaście kategorii tematycznych (41-48: dynastyczne, militarne, religijne, odniesienia do złotego wieku (saeculum aureum), euergetyzm, odniesienia do wydarzeń minionych, emisje niosące ideę odnowy (restitutor), emisje uwypuklające rolę rodziny cesarskiej oraz te, które prezentują neutralnie rolę cesarza, cnoty, ideę aeternitas, geograficzne, niepewne). Kryterium powyższego podziału stanowi treść monet, ich legenda i ikonografia. Skategoryzowany w ten sposób materiał badawczy stał się podstawą do wyróżnienia form cesarskiej propagandy na poziomie skali makro i mikro, a kwantytatywna analiza przeprowadzona dzięki zastosowaniu metod statystycznych, przyczyniła się do określenia stopnia natężenia propagowania treści ideologicznych w mennictwie rzymskim (s. 49).

Część pierwszą książki („General Patterns on Third-Century Imperial Coinage": 11-222) stanowią analizy mennictwa w skali makro. Tutaj Manders oparła się na materiale pogrupowanym w cztery najbardziej rozpowszechnione w ów-

\footnotetext{
${ }^{1}$ C.F. Noreña, The Communications of the Emperor's Virtues, JRS 91, 2001, s. 146-168; idem, Imperial Ideals in the Roman West: Representation, Circulation, Power, Cambridge Mass. 2011.
} 
czesnym mennictwie tematy: militarne (rozdział 2: 63-94), religijne (rozdział 3: 95-154), cnoty (rozdział 4: 155-185), saeculum aureum (rozdział 5: 187-220). $\mathrm{W}$ rozdziale 3 autorka rozważyła typologię monet poświęconych pięciu najpopularniejszym w mennictwie tego okresu bóstwom: Jowiszowi, Herkulesowi, Marsowi, Solowi i Apollonowi, następnie zajęła się osobą cesarza jako sacerdos oraz dokonała dwóch egzemplifikacji (Heliogabal i Aurelian), rezygnując tu $\mathrm{z}$ analizy w skali makro. W rozdziale 4 opracowała oddzielnie pięć kluczowych cnót: providentia (opatrzność, przewidywanie), liberalitas (hojność), virtus (męstwo), pietas (pobożność) i aequitas (sprawiedliwość, równość), podczas gdy $\mathrm{w}$ rozdziale 5 sporządziła i przeanalizowała typologię monet odnoszących się do saeculum aureum.

Drugą część opracowania („Case Studies”: 223-302) stanowią analizy typologii mennictwa w skali mikro. Przez pryzmat treści upamiętnianych za pomocą monet trzech wybranych cesarzy (Karakalla, Decjusz i Gallien), autorka podjęła próbę odtworzenia obrazu ich propagandy. Wzorem pierwszej części książki podzieliła monety według typów na trzynaście kategorii, a następnie na szerokim tle historycznym podjęła próbę ukazania propagandowego obrazu cesarza. Uzyskane w ten sposób wnioski Manders skonfrontowała z często odmiennym obrazem cesarza, jaki wyłania się ze źródeł literackich. Szczególnie interesujące zjawiska zaobserwować można w przypadku rządów Karakalli, kiedy nowe bóstwa - Pluton, Sarapis i Izyda - mogły odzwierciedlać być może konsekwencje Constitutio Antoniniana. Manders bowiem podkreśla, że na dobór treści namonetarnych w III wieku duży wpływ miały dwa czynniki: ówczesna rzeczywistość i bazujące na tradycji wyobrażenia.

Książkę kończy sześć aneksów (313-342: lista cesarzy, zestawienie monet z Jowiszem, Herkulesem, Marsem, Solem i Apollonem oraz innymi bóstwami według numeracji katalogowej „The Roman Imperial Coinage”, diachroniczny przegląd typów monetarnych Karakalli i Galliena), fotografie monet, zestawienie bibliograficzne (343-356) i indeks (357-363).

Niestety, od strony redakcyjnej publikacja ma kilka niedociągnięć. Indeks, nawet jeśli miał być z założenia wybiórczy, jest pozbawiony m.in. niektórych kluczowych dla przeprowadzanych analiz pojęć, często stanowiących elementy kategoryzacji monet (np. aeternitas, euergesia, paradeigmata, restitutor, saeculum aureum). Wykresy zostały zaopatrzone $\mathrm{w}$ niejasne legendy, a dokładniej - w niewyraźne oznaczenia, symbolizujące konkretne kategorie typologiczne (np. s. 49 i n.). Ponadto wszystkie wykresy z obliczeniami procentowymi zamieszczono $\mathrm{w}$ nietypowym i niewygodnym układzie (np. s. 51 i n.); brak również zestawienia końcowego wszystkich wykresów i reprodukcji monet. 
Zastosowana metodologia wzbudza wątpliwości. Nie wszystkie typy monet da się zakwalifikować do jednej tylko kategorii, czego Manders jest świadoma (zob. s. 48, przyp. 162). Legendy i ikonografia monet często bowiem posiadają wielorakie znaczenie i wzajemnie zazębiające się konteksty. Nie zawsze też odpowiednim kryterium będzie jedynie legenda, jak np. grupa „Aeternitas-messages”; pośrednio do idei wieczności państwa nawiązywały monety poświęcone wielu istotnym wydarzeniom lub świętom, np. upamiętnieniu rocznic panowań cesarzy, saeculum aureum, etc. Ponadto, jeśli kryterium klasyfikacyjnym było brzmienie legendy, to pominięto w omawianej grupie konsekracyjne monety ku czci Klaudiusza Gockiego z 270 r., propagujące Memoria Aeterna. Niekiedy odczuwa się brak komentarza wyjaśniającego kryteria, jakimi kierowała się autorka, zaliczając te czy inne monety do danej kategorii, tudzież precyzującego różnice terminologiczne (np. pomiędzy pojęciami aeternitas, perpetuitas, semper; pomimo pewnego pokrewieństwa znaczeniowego terminy te różnią się jednak od siebie, choćby pod względem etymologicznym). Niestety, Manders wybiórczo włączyła do swoich analiz mennictwo Sewerów. Pisząc na przykład o koncepcji Aeternitas Imperii (s. 130, przyp. 157), wzięła pod uwagę tylko mennictwo Filipa II i Karusa, pomijając czołowych propagatorów tej idei - Sewerów (RIC IV.1, Septimius Severus 155 a, b; 174; 178a, etc.). Minusem przyjętej metodologii jest również rezygnacja $\mathrm{z}$ analizy typologii monet przez pryzmat nominałów. Ich sprecyzowania zabrakło również w podpisach pod zamieszczonymi w książce reprodukcjami monet. W odniesieniu do tych ostatnich autorka nie określiła także skali, w jakiej monety zostały przedstawione (1:1 czy innej).

Recenzowany tom, pomimo omówionych zastrzeżeń, jest cennym wkładem w rozwój badań nad ideologią i propagandą cesarską przez pryzmat mennictwa imperialnego. Analiza tak obszernego zespołu monet unaocznia wielość i różnorodność możliwości badawczych w tej dziedzinie. 